\title{
Kliniksel Denetim Modelinin Mesleki ve Teknik Anadolu Lisesinde Uygulanabilirliği İle İlgili Yönetici ve Öğretmen Görüşleri
}

\section{Administrative and Teacher Opinions on the Applicability of the Clinical Control Model in the Vocational and Technical Anatolian High School}

Süleyman Göksoy, Düzce Üniversitesi, Eğitim Fakültesi, suleymangoksoy@duzce.edu.tr Zeynep Öztürk, Milli Ĕgitim Bakanlı̆̆ı, zeynepyumnu@gmail.com

Öz. Klasik denetim yaklaşımları ve oluşturdukları imaj, denetime karşı olumsuz bir bakış açısı geliştirmiş olmakla beraber, denetim, yalnızca olanı ortaya koymaya çalışmaktan öteye geçememiştir. Günümüzde artık yeni denetim yaklaşımlarına ihtiyaç duyulduğu açıktır. Bu yaklaşımlar öğretmenin denetime olan bakış açısını değiştiren, kendisini mesleki anlamda geliştiren, öğretmen-denetmen işbirliğini doğuran etkili uygulamalar olmalıdır. Bu araştırmada, Çağdaş Denetim Yaklaşımlarından biri olan Kliniksel Denetimin, Mesleki ve Teknik Anadolu Lisesi'nde uygulanabilirliği ve öğretmenlerin bu yaklaşımın aşamaları ve alt boyutlarına bakıș açıları, bir nitel araștırma türü olan durum çalıșması ile ortaya konulmaya çalıșılmıștır. Bu kapsamda 8 öğretmen ile görüşülmüş ve Kliniksel Denetim Yaklaşımının alt temalarını yansıtan sorular yöneltilmiștir. Verilen cevaplar doğrultusunda katılımcıların yalnızca 4'ünün Kliniksel Denetim'in bütün aşamalarına olumlu baktığı, diğer 4 öğretmenin ise kısmen olumlu bulduğu görülmüştür. Sonuç olarak bu yöntemin kullanılmasının olumlu sonuç vermeyeceği kanısına varılmıștır. Ayrıca öğretmenlerin bu denetim yaklaşımlarıyla ilgili eğitim almalarının, bakış açılarını değiştireceği düşünülmektedir.

Anahtar Sözcükler: Eğitim Denetimi, Kliniksel Denetim, Çağdaş Denetim Yaklaşımları

\begin{abstract}
In this study, the applicability of Clinical Supervision, which is one of the Contemporary Supervision Approaches, at Vocational and Technical Anatolian High School and the perspectives of teachers on the steps and sub-dimensions of this approach have been tried to be revealed by the case study which is a kind of qualitative research. In this context, 8 teachers were interviewed and questions reflecting the sub-themes of the Clinical Control Approach were directed. Only 4 of the respondents saw positive responses to all phases of the Clinical Supervision, while 4 of the respondents found it positive in the direction of the answers given. As a result, it has come to the conclusion that using this method will not have a positive effect. It is also thought that teachers' training on these supervisory approaches will change their perspective.
\end{abstract}

Keywords: Training Supervision, Contemporary Supervision Approaches, Clinical Supervision 


\section{SUMMARY}

\section{Introduction}

From past to today, classical models have dominated education supervision. This has put an already tense mechanism into a more problematic and unwanted situation since the past. Whatever the supervisor is, there is a pressure on whom supervised and it creates uneasiness. Although this has increased the need for new approaches of supervision, the idea of abolishing supervision altogether has never been conceived. Because the concept of supervision is a concept that must always be constructive, directive, and expressive. The Contemporary Supervision Approaches that have emerged for this purpose provide a constructive, modern understanding that leads to the real purpose of supervision.

\section{Methodology}

In the research, qualitative research method was used in order to make an in-depth analysis of the perspective of clinical supervision approach. The reason for preferring the qualitative research method is to make it possible for the interviewees to express themselves in a way that contributes to the research by making explanations through mutual negotiations because of lack of sufficient preliminary knowledge about clinical supervision. Interview techniques were used in the research data to ensure data diversity were collected with semistructured interviews in schools and classrooms and unstructured unattended observations. The questions prepared to be addressed to the participants are the open-ended questions, which are inspired by the subactivities of clinical supervision shown in Table 1 of the themes of the preliminary interview, observation, analysis and planning, final interview and criticism and by various researches in the literature. In total, 26 questions were identified, the first 8 of these questions were "preliminary interviews", 9, 10, 11 and $12^{\text {th }}$ questions were "observation", 13, 14, 15 and $16^{\text {th }}$ questions were "analysis and planning", 17, 18, 19, 20, 21 $1^{\text {st }}$ and $22^{\text {nd }}$ questions were the "last meeting" and 23, 24, 25 and 26th questions were the "criticism". During the interview, participants were able to express their ideas with non-directional explanations correctly so that they could comment. The interviews were made at the places and time where the participants felt comfortable and they were provided to give sincere answers by presenting preliminary information about the research.

\section{Results}

Sampling method for research purpose was used and semi-structured interviews and observations were made with 3 administrators and 5 teachers in Vocational and Technical Anatolian High School. A gradual process was followed in the research samples, interviews were made with teachers first, and a process from general to specific was followed with in-school observations. There are 3 administrators and 5 teachers who participated in the interview. Two of them were from Foreign Language, five of them were from Health Service Fields, and one of them was from Guidance Teaching. Three of the participants were male, five of them were females. It was aimed to have diversity by taking the opinions of administrators and teachers in the research, but when the situation in the classroom was discussed, there was no manager-teacher difference in terms of opinions.

\section{Discussion and Conslusion}

In the study, the opinions of the administrators and teachers working in Vocational and Technical Anatolian High School about the sub-topics of clinical supervision were taken and the interviews were analyzed. According to the result of the analysis made, traces of classical supervision approaches were seen in the opinions of the teachers. Some of the teachers found some parts of the clinical supervision approach unnecessary. They argued that supervisors should 
not be involved in the controlling process, only observation they should do. It has come to the conclusion that the implementation of the clinical supervision approach without any training at Vocational and Technical Anatolian High School will be ineffective but can be implemented after the teachers have a positive view of the process with regard to this approach and the clinical supervision has been adequately introduced. 


\section{Gİiș}

Eğitim denetimiyle ilgili olarak geçmişten günümüze bir çok model geliştirilmiş olmasına rağmen genellikle klasik modeller hakim olmuş, yenilikçi ve çağdaş bir denetime tam manasıyla geçilememiştir. Bu durum geçmişten beri zaten doğasında gerginlik olan bir mekanizmayı daha da sorunlu ve istenmeyen bir durum haline sokmuştur. Denetleyen kişi kim olursa olsun denetlenen üzerinde bir baskı unsuru olmakta ve huzursuzluk yaratmaktadır. Bu durum yeni denetim yaklaşımlarına olan ihtiyacı artırmış olmasına rağmen, denetimin tamamen ortadan kaldırılması fikri hiçbir zaman akla getirilmemiştir. Çünkü denetim kavramı her zaman gerekli olduğuna inanılan, yapıcı, yönlendirici ve resmedici olması gereken bir kavramdır.

Erişmen (2008), özellikle denetimin, durumun fotoğrafını çeken, düzelten-geliştiren, değerlendiren ve bu sayede üç öğenin birleșimi olan bir yapı oluşturduğunu ifade etmektedir. Denetim, denetmen ve öğretmenlerin kendi uygulamaları hakkında fikir sahibi olmalarını, yaptıkları ile ilgili olarak ayrıntılı bilgi sahibi olmalarını ve kazanılan bilgi, becerileri okul, sınıf içerisinde en etkili ve verimli düzeyde kullanabilmelerine yardım eden bir süreçtir.

Denetim gerekli midir? Eğitimde geliștirici olmayan bir denetimin ișlevinin sorgulanması olağan karşılanmaktadır fakat çok iyi bildiğimiz bir şey vardır ki o da denetimsiz bir sistem düşünülemeyeceğidir. Ancak, denetimin șekli, içeriği, yöntemi değișebilir. Tabii ki denetim deyince mutlaka birilerinin dışardan kontrol etmesi düşünülmemelidir. Kişinin içsel denetimi, kurumların kendi iç mekanizmalarının harekete geçmesi şeklinde de olabilir (Şişman, 2014). Eğitimde denetimin gerekliliğini vurgulayan bir diğer unsur da denetimin bu gün artık kontrol etmekten öte geliştirme odaklı bir işlev içinde görülmesidir. Bu nedenle özellikle öğretimin denetimi ve geliştirilmesi eğitim sisteminin amaçlarına ulaşmasında en gerekli unsurlardan biri haline gelmiştir (Aydın, 2012). Eğer öğretimde amaçlanan hedeflerin en yüksek düzeyde gerçekleşmesi isteniyorsa denetime gereken önem verilmeli; değişen, gelişen durumlara ayak uydurmak için yol ve yöntemler belirlenmelidir.

Denetimin gerekliliğini anlayabilmek için amaçlarının doğru şekilde ortaya konması gerekmektedir. Bununla ilgili olarak Glickman, Gordon ve Ross-Gordon'un aktarımına göre bir takım tanımlamalar görülmektedir: Bob Reynolds'a (2014) göre denetimin amacı, öğretmenleri öğretim stratejilerinin etkili olup olmadığını öğrenmek için gözlemlemektir. Jan White ise denetimin amacını öğretimin geliştirilmesi için araştırmaya yöneltmek olması gerektiğini, denetmen ve öğretmenin sorunları paylaşmaları gerektiğini, çözüm önerilerini ve geliştirme planını birbirine sunması ve birlikte bir karara varmaları gerektiğini söylemiştir. Günümüzde bu denetim yaklaşımlarını uygulayabilmek için yasal düzenlemeler gerekmekte, hangi yöntemin nerede kullanılacağına karar vermek için de denetçinin ve denetlenen kişilerin kişisel özellikleri önem arz etmekte ve yaklaşımların bu şekilde belirlenmesi gerekmektedir (Karakuş, 2010). Ayrıca bu denetimlerin profesyonelce uygulanıp başarıya ulaşmaları için denetmenlerin de deneyimli olmaları, eğitim-öğretim konularına hakim olmaları, denetlenen öğretmenlerden daha deneyimli olmaları, programlara hakim olmaları ve öğretmenlerin de denetmeni rehber olarak kabul etmeleri gerekmektedir (Yavuz, 1995).

Denetimde etkililiğin yakalanabilmesi için öğretmenlerin denetime olan bakış açıları önem arz etmektedir. Öğretmen denetmeni başvurulacak kişi olarak görmeli, konusundaki otoritesini tanımalı, aynı zamanda kendisini denetmene karşı rahat hissetmelidir. Yavuz'un (1995) yaptığı araştırma sonuçları öğretmenlerin denetim konusundaki görüşleri, klasik denetimin izlerini göstermektedir. Öğretmenler denetmenleri başvurulacak kişi olarak görmemekte, denetimden uzak kalmak istemekte, denetmenlerin iletişimini yetersiz bulmakta, isteksiz kalmaktadırlar. Bu sonuçlar öğretmenlerin çağdaş denetim yaklaşımlarına olan ihtiyacını ortaya koymaktadır. Özan ve Şener (2015) tarafından yapılan araştırmaya göre de, denetim sürecine ilişkin olumsuz algıya sahip öğretmenler, bunun gerekçesi olarak denetimin açık aramak ve kontrol amaçlı yapıldığını, bu durumun ise baskı ve korkuya neden olduğunu ileri sürmüşlerdir. Bu bulgular okullarımızda gerçekleştirilen denetim sürecinde, bilimsel, klasik denetim modelinin uygulandığının sinyallerini vermektedir. Buna karşın olumlu algıya sahip öğretmenler, denetimin yapılan çalışmaların değerlendirilmesi, eksikliklerin tespit edilmesi ve bu eksikliklerin giderilmesi, istenilen başarı düzeyine ulaşılması, süreç gelişiminin sağlanarak aksayan yönlerin iyileștirmesi ve sistemin varlığını devam ettirmesi için geleceğe yatırım olarak görmüşlerdir. Bu 
görüşlere bakınca da daha çok çağdaş denetim yaklaşımlarının izleri görülmektedir. Sonuçlar genel olarak incelendiğinde; eğitim denetmenlerinin denetim görevini yürütürken, çoğunlukla bilimsel denetim yaklaşımına uygun bir denetim ortamı oluşturdukları ve bunun sonucunda öğretmenlerin denetime bakış açllarının olumsuz hale büründüğü söylenebilir. Anlaşıldığı kadarıyla öğretmenler denetimin daha çok şeffaf, tarafsız, adaletli, rehberlik yönünün ön plana çıktığı bir iş birliği yaklaşımı şeklinde yapılmasını istemektedirler (Özan ve Şener, 2015).

Çağdaş denetim yaklaşımlarını klasik yaklaşımlardan ayıran özellik insan kaynaklarını geliştirmesi ve etkili bir şekilde kullanmasıdır. Ayrıca öğretimi geliştirmeyi de ön planda tutmasıdır (Yavuz, 1995). Çağdaş eğitimde denetim, öğretmeyi ve öğrenmeyi etkileyen faktörlerin tümünün değerlendirilmesi ve daha etkili öğretme-öğrenme ortam ve koşullarının hazırlanması işidir. Çağdaş eğitim denetimi, teknik ve sosyal bir süreçtir. İnsan ve madde kaynaklarının etkili bir biçimde kullanılması ve geliştirilmesi amacıyla uygulanır. Tanılama, değerlendirme ve geliştirme işlevlerini içerir (Kurt, 2009). Çağdaş denetim yaklaşımlarında denetimde esas faktör olan iç denetim mekanizmalarını harekete geçirmek amaçlanır. Öğretmen denetime isteklidir, kendi sorumluluklarının farkındadırlar, üzerlerinde denetçi baskısını hissetmezler, kendi kendilerini değerlendirirler. Denetim kavramı anlık bir durum tespitinden çok gelişimsel bir süreç halini alır, mesleki ve sürekli gelişimi baz alır, sürekli öğrenmeyi sağlar ve öğretmenlerin kendilerini geliştirmeleri için güdüleyecek bir mekanizma, bir araç olarak görülmektedir (Erişmen, 2008: Karakuş, 2010). Yani denetim, öğretmenin kendisini ve öğretimi denetlemesi için bir araç ve denetmen ise bunun için yol gösteren bir rehber konumundadır.

Çağdaş denetim, öğretimle ilgili olan herkesle işbirliği içindedir. Çıkabilecek sorunların çözümü için bilimsel yöntemlere başvurarak nesnel, olgulara ve gerçek verilere dayalı araştırmalar sonucu değerlendirmeler yapar ve öneriler geliştirir. Öğretimin etkili olabilmesi için her aşamaya öğretmenle karar verilir. "Neden oldu?" sorusundan çok, "Nasıl daha iyi olabilir?" sorusuyla ilgilenilir (Yavuz, 1995).

Yapılan araştırmalarla çağdaş denetim yaklaşımlarının önemi gözler önüne serilmektedir. $\mathrm{Bu}$ yaklaşımlardan birisi de kliniksel denetimdir. Kliniksel denetim, Robert Goldhammer ve arkadaşları Morris Cogan tarafından geliştirilen bir denetim modelidir. Bu modelde bazı aşamalar vardır. Bu aşamaların her birine ait etkinlikler bittikten sonra bir diğer aşamaya geçilir. Daha sonra tekrar en başa dönülerek denetimin sürekliliği sağlanmış olur. Odak noktası öğretim ve öğretimin niteliğini artırmaktır (Yavuz, 1995). Bilinmelidir ki kliniksel denetim adının çağrıştırdığı gibi bir hasta-doktor ilişkisini değil, öğretmen-denetçi işbirliğini ve mesleki gelişimi ifade eder (Editör: Sağır ve Göksoy, 2016, 154). Klinik kavramına, öğretmenlerin denetiminde patolojik yanların düzeltilmesi gibi bir yan anlam yüklenmemelidir. Kliniksel denetim her zaman öğretmenin göstermiş olduğu yetersiz davranışların denetmen tarafından iyileştirilmesi süreci olarak görülmemeli, bu anlayışlardan kaçınılmalıdır. Kliniksel denetim daha çok "öğretmen merkezli denetim" ifadesi ile açıklanabilmektedir (Cogan,1973. Akt.: Erişmen, 2008). Kliniksel denetimde, denetçi ile denetlenen, karşılıklı güvene dayalı iş birliği içinde, problemleri birlikte tespit edip, bu problemlere birlikte çözüm üretmektedirler (Karakuş, 2010). Görüldügü üzere kliniksel denetim, tam da öğretmenlerin istedikleri gibi, rahatlatıcı ve yol gösterici, sorun çözücü bir çağdaş denetim yaklaşımıdır.

Kliniksel denetimin özelliklerini şu şekilde sıralayabiliriz: Sınıfa dayalıdır, öğretimi iyileştirirken öğretmenin mesleki gelişimini sağlamayı amaçlar, toplam değerlendirmeden farklıdır, denetmenin pedagojik yeterliliği gereklidir, denetmenin iletişim yönünün iyi olması gerekir, önyargısızdır, güven temellidir, öğretmen ve denetmen eşit olarak görülür, veriye dayalıdır, öğretmenlerin gözlemlenen derse ilişkin endişe ve ilgilerine dayalı veriler toplar, yansıtıcı bir diyalog ister ve beş adımlı kliniksel döngü düzenli olarak devam eder (Editör: Aksu ve Ağaoğlu, 2014, 242).

Oldukça sistematik ve sürekli-döngüsel olduğu görülen kliniksel denetim, diğer yandan demokrasiyi ve sağlıklı insan ilişkilerini de doğurur. Bu denetim yaklaşımı denetimi baskı unsuru olmaktan çıkarıp, geliştirici olmayı amaçlar.

Erişmen (2008) kliniksel denetimin amaçlarını şu şekilde sıralamıştır: öğretmenlerin kişisel analizci olmalarını sağlamak, öğretmenlere objektif geri besleme sağlamak, öğretim problemlerini teşhis etmek ve çözmek, öğretmenlerin çeşitli eğitimsel stratejiler kullanmalarını sağlamak, 
öğretmenleri, hatırlama, yükselme, iş ahlakı gibi konularda değerlendirmek ve Milli Eğitimin amaçlarından olan hayat boyu öğrenme için olumlu bir ortam oluşturmaktır.

$\mathrm{Bu}$ amaçlar doğrultusunda, denetmen ve öğretmen arasında bir ortaklık ve fikir paylaşımını geliştirirken, öğretmenin öğretimsel becerilerinin iyileștirmesini sağlar. Bunun yanında ne yazık ki kliniksel denetimin yerleştirilmesinde bürokratik ve sosyal zorluklar, örgüt yapısı görüşme ve gözlem aşamaları için yeteri kadar zamana imkan tanımaması gibi engeller bu yaklaşımın uygulanması ile ilgili sınırlılıklar arasında gösterilmektedir (Erişmen, 2008).

Kliniksel denetimin uygulama süreci beş adımdan oluşmaktadır. Her bir aşamanın alt etkinlikleri bulunmaktadır. Bu etkinlikler sıra ile şu süreçleri içerir:

i. Ön Görüşme: Gözlemin yapılması için her iki taraf için de en uygun olan zaman seçilerek, nelerin gözlemleneceği birlikte netleștirilir. Gözlemin nedeni ve amacı ortaya çıkarılır.

ii. Gözlem: Ön görüşmedeki kararlar gerçekleştirilir. Gözlemin amacı betimlemedir. Gözlemci betimleme ile yorumlama arasındaki farkı ayırdetmelidir. Öğretmenin sınıf içi etkinlikleri gözlemlenirken denetçi; öğretmenin kendisini tehdit altında hissederek strese girmesini önlemeli, empatik bir şekilde öğretmeni anlamaya çalışmalı, yapay davranışların oluşmasını önlemek için sınıf içindeki varlığını hissettirmemeli, önemsiz detayları önemli olanlardan ayırt etmeli, gözlemi modern ve güvenilir araçlarla kayıt altına almalı, öğretmeni bütün yönleriyle ve içinde bulunduğu durumsal koşulları da göz önünde bulundurarak değerlendirmelidir (Glickman, vd. 2014, 243: Akt. Karakuş, 2010).

iii. Çözümleme ve Planlama: Denetmen kendi gözlemlerini gözden geçirmek için yalnız kalacağı bir yer arar, gözlemi sırasındaki temel hatları belirler, özetler, nasıl bir yaklaşımla bunları paylaşacağını belirler. Bunu belirlerken öğretmenin gelişim düzeyini göz önünde bulundurur (Editör: Aksu ve Ağaoğlu, 2014) .

iv. Son Görüşme: Gözlem sonrası görüşme, gözlemin ardından olabildiğince çabuk yapılmalıdır. Burada denetçi, öğretmenin kişiliğine yönelik değil, onun davranışlarındaki eksik veya hatalı unsurlara yönelik eleștiriler yapmalıdır. Öğretmenin uygulamalarıyla ilgili olarak hem olumlu hem de olumsuz yönler tartışılmalı, eğer bir değişim ihtiyacı varsa bunun nasıl gerçekleștirilebileceği konuşulmalıdır. Eğitim öğretimin etkililiği odağa alınarak, elde edilen veriler ışığında, öğretmenin profesyonel gelişiminin devamlılı̆̆ının nasıl sağlanabileceği tartışılmalı ve bunlar için birlikte bir planlama yapılmalıdır (Akt. Karakuş, 2010).

v. Eleştiri: Önceki dört aşama için yöntem ve teknik konusunda yolunda gitmeyen veyahut düzeltilmesi gereken noktaların gözden geçirilmesidir. Bu aşama denetmenin de yöntemini geliştirme çabası içinde olduğunu gösterir (Aksu ve Ağaoğlu, 2014, 244).

Aksu ve Ağaoğlu $(2014,246)$, Kliniksel denetimin adımlarına yönelik eylemleri aşağıda Tablo 1'de gösterildiği şekilde tablolaştırmıştır.

“Tablo 1. Kliniksel Denetimin Adımlarına Yönelik Eylemler

\begin{tabular}{|c|c|c|}
\hline Adım & & Belirli Etkinlikler \\
\hline \multirow{8}{*}{\multicolumn{2}{|c|}{ Ön Görüşme }} & Görüșmeye olumlu tarzda bașlama \\
\hline & & Öğretmenin ders planını tartıșma \\
\hline & & Dersle ilgili endișelerini tartıșma \\
\hline & & Gözlemlenecek davranıșları tartışma \\
\hline & & Bir gözlem aracı geliștirme veya seçme \\
\hline & & Gözlemin biçimini tartıșma \\
\hline & & Görüșme kararlarını gözden geçirme \\
\hline & & Görüșmeyi olumlu tarzda bitirme \\
\hline \multirow{2}{*}{\multicolumn{2}{|c|}{ Gözlem }} & Verileri toplama \\
\hline & & Betimleme yapma, yorumlamadan kaçınma \\
\hline \multirow{4}{*}{\multicolumn{2}{|c|}{$\begin{array}{l}\text { Çözümleme } \\
\text { Planlama }\end{array}$}} & Verileri çözümleme \\
\hline & & Verileri özetleme \\
\hline & & Son görüșme için yaklașımı belirleme \\
\hline & & Son görüșmeyi planlama \\
\hline \multirow[t]{3}{*}{ Son Görüşme } & & Olumlu tarzda bașlama \\
\hline & & Ön görüșme kararlarını gözden geçirme \\
\hline & & Gözlem verilerini paylașma ve açıklama \\
\hline
\end{tabular}




\begin{tabular}{|c|c|}
\hline & Tartıșma ve birlikte yorumlama \\
\hline & Geliștirme hedeflerini belirleme \\
\hline & Eylemleri planlama ve kaynakları tartıșma \\
\hline & Planı değerlendirme ölçütlerini tartışma ve izleme \\
\hline & Görüșme kararlarını gözden geçirme \\
\hline & Olumlu tarzda bitirme \\
\hline Eleştiri & Ön görüșmeyi eleștirme \\
\hline & Gözlem sürecini eleștirme \\
\hline & Öğretmene sunulan gözlem verilerini elestirme \\
\hline & Son görüșmeyi eleștirme \\
\hline & Kliniksel denetimi geliștirme yollarını tartıșma \\
\hline
\end{tabular}

Kliniksel denetim; eğer okul eğitim programları öğretmenlerin ne yaptıklarıyla ilgili ise, denetim öğretmenin de sorumluluğu olarak görülüyorsa, denetimin odak noktası öğretmenin güçlü yönleriyse etkili olabilir. Ayrıca doğru koşullar yaratıldığında öğretmenler ilerleme istek ve yeteneğine sahipse, öğretmenler genellikle geniș bir beceri hazinesine sahipse ve öğretmenler meydan okuyucu işten doyum elde ederse etkili bir şekilde kullanılabilir. Bunlar kliniksel denetimin varsayımlarıdır. Böylece, kliniksel denetim, eğitimin geliștirilmesinde denetçi ve öğretmenin bir ortaklığı olarak görülmekte ve denetçi rolünü üstlenen kişinin deneyimleri ve davranışlarıyla daha çok rehber ve yol gösterici olduğu belirtilmektedir (Sergiovanni ve Starrat, 1988, Akt. Özmen, 2000, 123).

Kayıkçı, Cantürk ve Yılmaz'ın (2014) yaptığı araştırmaya göre, okul müdürlerinden beși, kliniksel denetimle, insan ruhuna ve onuruna uygun bir denetim sisteminin gelmiș olacağını belirtmișlerdir. Üç okul müdürü, kliniksel denetimin okuldaki kaygıları ve korkuları gidereceğini ve okulun gelișimine katkı sağlayacağını belirtmişlerdir. İkișer okul müdürü ise, "kliniksel denetimin, eleştirmek veya eksik aramaktan ziyade problemin hissedilmesini, tanınmasını ve çözümünü sağlayacağını; öğretmenin göremediği eksiklikleri bulunmasını, objektif, yapıcı ve gerçekçi bir değerlendirme yapılmasını sağlayacağını; öğretmenin performansını arttıracağını; yapılan denetimlerin kâğıt üzerinde kalmamış olacağını" belirtmişlerdir. Bir okul müdürü ise kliniksel denetimle planlı bir eğitim sisteminin oluşacağını savunmuştur. Çalışma grubunda yer alan okul müdürlerinin kliniksel denetim yaklaşımına ilişkin genel görüş ve değerlendirmeleri dikkate alındığında okul müdürlerinin tamamına yakınının kliniksel denetime ilişkin görüşlerinin olumlu ve çok olumlu olduğu ortaya çıkmıştır. Bu sonuçlar katılımcı okul müdürlerinin kliniksel denetimi benimsediklerini göstermektedir (Kayıkçı, Cantürk ve Yılmaz, 2014). Fakat bu güne kadar her zaman klasik yöntemlerle denetlenmiş ve çağdaş denetim yaklaşımları ile tanışmamış, geleneksel yöntemleri benimsemiş olan öğretmen ve denetmenlerin kliniksel denetimi anlamaları ve benimsemeleri güçleşmektedir.

Bu araştırmada Mesleki ve Teknik Anadolu Lisesi'nde farklı bir denetim modeli olan ve belli aşamalardan oluşan kliniksel denetim ele alınmıștır. Araştırmada özel ve derinlemesine bir çalışma olması açısından kliniksel denetim yaklaşımı üzerine çalıșılmıștır. Mevcut araștırma ile, Mesleki ve Teknik Anadolu Lisesi'nin öğretmen ve yöneticilerinin çağdaş denetim yaklaşımlarından biri olan kliniksel denetimin uygulanabilirliğine ilişkin;

1. Öğretmen ve yöneticilerin denetime bakış açısını tanımlamak,

2. Öğretmenlerin denetmenden beklentilerini ortaya koymak,

3. Öğretmen ve yöneticilerin kliniksel denetim yaklaşımına yönelik bakış açısını betimlemek,

4. Kliniksel yaklaşımın kurum içerisinde uygulanabilirliğini yordamak,

5. Denetimle ilgili görüşlere bakılarak kurumda geliștirilebilecek yönleri ortaya çlkarmak,

6. Elde edilen verilerin diğer eğitim kurumları, eğitim sistemi yöneticileri, denetmenleri ve eğitimcilerin faydasına sunularak yol göstermesini sağlamak,

7. Benzer bir araştırmanın başka kurumlarda da yapılması için fikir vermek,

8. Kliniksel denetim ile ilgili yöneticilere yönelik araştırmalardan farklı olarak, denetlenen kişiler olan öğretmenlerin de görüşlerini ortaya çıkarmak, 
9. Yapılacak diğer akademik araştırmalara katkıda bulunmak amaçlanmıştır.

\section{YÖNTEM}

\section{Araştırmanın Modeli}

Araştırmada, kliniksel denetim yaklaşımına bakış açılarının derinlemesine analizini yapabilmek amacıyla nitel araştırma yöntemi ve nitel araştırma desenlerinden durum çalışması kullanılmıştır. Durum çalışması ağırlıklı olarak nitel araştırma yöntemlerinin özelliklerini taşıyan bir desen olup araştırılan konunun derinlemesine incelenmesine imkan tanır. Eğitimin çeşitli konularını anlamada özellikle ne, nasıl, niçin soruları yöneltildiğinde tercih edilen bir yönetemdir (Yıldırım ve Şimşek, 2008; Yılmaz, 2015). Bu doğrultuda araştırmada kliniksel denetim yaklaşımı, öğretmenler ve yöneticilerin görüşleri alınarak ve katılımsız gözlem ile yazılı kaynaklardan yola çıkılarak betimleneceği için araştırma, nitel araştırma desenlerinden durum çalışması tercih edilerek, verilerin toplanması ve analizi yapılmıștır.

\section{Araştırmanın Çalışma Grubu}

Mesleki ve Teknik Anadolu Liseleri, özel alanda eğitim veren, meslek dersi ve kültür dersi öğretmenlerinin bir arada bulunduğu okullardır. Ayrıca ülkemizde son yıllarda mesleki ve teknik eğitimin geliştirilmesi gerekliliği vurgulanmaktadır. Bu okulun seçilmesinin nedeni bir meslek lisesinde görev yapan yöneticilerin, kültür ve meslek dersi öğretmenlerinin görüşlerinin alınmak istenmesidir. Böylelikle diğer okullardan farklı bir çalışma sistemi olan bu okullarda görev yapan öğretmen ve yöneticilerin denetime bakış açısı yorumlanacaktır.

Araştırmada amaçlı örnekleme yöntemlerinden olan tipik durum örnekleme yöntemi kullanılmış ve Mesleki ve Teknik Anadolu Lisesi'ndeki gönüllülük esasına göre belirlenen 3 yönetici ve 5 öğretmen ile yarı yapılandırılmış görüşme ve gözlem yapılmıştır. Araştırma örneklemlerinde aşamalı bir süreç izlenmiş, önce yönetici ve öğretmenler ile görüşmeler yapılmış, okul içi gözlemlerle de genelden özele bir süreç izlenmiştir.

Tablo 2. Katılımcllara Ait Bilgiler

\begin{tabular}{llll}
\hline Kod & Cinsiyeti & Ünvanı & Branşı/Sınıfı \\
\hline Ö1 & E & Öğretmen & Yabancı Dil \\
Ö2 & K & Yönetici & Yabancı Dil \\
Ö3 & E & Öğretmen & Sağlı Hizmetleri Alanı \\
Ö4 & E & Ögretmen & Sağlı Hizmetleri Alanı \\
Ö5 & K & Yönetici & Sağlı Hizmetleri Alanı \\
Ö6 & K & Yönetici & Sağlı Hizmetleri Alanı \\
Ö7 & $\mathrm{K}$ & Öğretmen & Rehberlik \\
Ö8 & $\mathrm{K}$ & Öğretmen & Sağlı Hizmetleri Alanı \\
\hline
\end{tabular}

Görüşmeye katılan 3 yönetici, 5 öğretmen bulunmaktadır. Katılımcılardan 2'si Yabancı Dil (İngilizce), 5'i Sağlık Hizmetleri Alanı, 1'i de öğrencilerle birebir etkileşimde bulunan ve okulda gerek seminer yoluyla ve gerekse bireysel olarak okulun dahil olduğu proje konularıyla ilgili (madde bağımlılığı, ergenlik gibi) öğretime dahil olan Rehber Öğretmendir. Katılımcılardan 3'ü erkek, 5’i kadındır. Araştırmada yönetici ve öğretmen görüşleri alınarak çeşitlilik olması amaçlanmış fakat ders içi durum konuşulduğundan, görüşler açısından yönetici-öğretmen farkı ortaya çıkmamıştır.

\section{Veri Toplama Aracı}

Araştırmada görüşme tekniği kullanılmış, geçerliği ve güvenirliği artırmak için görüşmeler yazı ile kayıt altına alınmış olup; veri çeşitliliğini sağlamak için araştırma verileri, okul ve sınıflardaki yarı yapılandırılmış görüşme, yapılandırılmamış katılımsız gözlemler ile toplanmıştır. Katılımcılara yöneltilmek üzere hazırlanan sorular kliniksel denetimin aşamaları olan "ön görüşme”, “gözlem”, “çözümleme ve planlama”, "son görüşme” ve "eleştiri” temalarının Tablo 1'de 
gösterilen alt etkinliklerinden ve alan yazındaki çeşitli araştırmalarda ilham alınarak belirlenen açık uçlu sorulardan oluşmaktadır. Toplamda 26 soru belirlenmiş, bu soruların ilk 8'i "ön görüşme", 9, 10, 11 ve 12. sorular "gözlem", 13, 14, 15 ve 16. sorular "çözümleme ve planlama", $17,18,19,20,21$ ve 22. sorular "son görüşme" ve 23, 24, 25 ve 26. sorular "eleştiri" temalarını yordamaktadır. Katılımcıların yorum yapabilmeleri için görüşme sırasında yönlendirici olmayan açıklamalar yapılmış fikirlerini doğru şekilde ifade etmeleri sağlanmıştır. Görüşmeler esnasında verilen yanıtların birbiriyle ve diğer katılımcıların verdikleri cevaplarla tutarlı olduğu görülmüştür.

\section{Verilerin Analizi}

Katılımclların isimleri gizlenerek belli kodlar verilmiștir. Bu kodlar “Ö1, Ö2, Ö3,..” şeklinde belirlenmiştir. Araştırmada elde edilen veriler nitel araştırma yöntemi kapsamında betimsel analiz ile yapılarak, tümevarımsal bir sonuca ulașılarak yorumlanmıștır. Elde edilen bulgular sade ve anlaşılır ifadelerle betimlenmiş, çıkarımlar sebepleriyle birlikte belirtilerek yazılmıștır.

Araştırmanın geçerliliği ve güvenirliğini sağlamak için; araştırmada kullanılacak sorular, Glickman, ve diğerlerinin (2014) ifade ettiği kliniksel denetimin adımlarına yönelik eylemlere göre oluşturulmuş olup, açık uçlu hazırlanmıştır. Öğretmen ve yöneticilerle bireysel olarak görüşme talep edilmiş, gönüllü olanlar ile çalışma yapılmıştır. Görüşmeler, katılımcıların kendilerini rahat hissedecekleri yer ve zamanlarda yapılmış, araștırma ile ilgili ön bilgilendirme yapılarak samimi cevaplar vermeleri sağlanmıștır. Her bir görüşme yaklaşık olarak yirmi dakika sürmüştür. Görüşmeler kağıt üzerinde, katılımcıların izni alınarak kayıt altına alınmıştır. Değerlendirme aşamasında objektiflik sağlanabilmesi için kağıtlara kodlar verilmiştir.

\section{BULGULAR}

Araştırma bulguları görüşmeler ve gözlemler olarak iki bölümde analiz edilmiştir. Birinci bölümde Glickman ve diğerlerinin (2014), belirttiği kliniksel denetimin beş temasına göre başlıklar şeklinde katılımcıların yorumlarının analizi yapılmıştır.

\section{1. Ön Görüşme}

$\mathrm{Bu}$ aşamada öğretmenlerin kliniksel denetimin "ön görüşme" temasına ait görüşleri alınmıştır. Denetlemeye gelecek olan kişi öncesinde sizinle görüşme yapmalı mı, bu görüşmede neler konuşulmalı, nasıl bir ortamda ve kimlerle olmalı, denetleyicinin tutum ve tavrı nasıl olmall, denetleme zamanı önceden bildirilmeli mi, denetleme kriterleri paylaşılmalı mı şeklinde sorular yöneltilmiştir. Alınan cevaplara göre aşağıdaki tablo oluşturulmuştur.

Tablo 3. 'Ön görüșme' temasına ilișkin sorular ve katılımcı görüșleri

\begin{tabular}{|c|c|}
\hline Sorular & Katılımcı Görüşleri \\
\hline $\begin{array}{l}\text { 1.Sizi denetlemeye gelecek kişi sizinle ön görüşme } \\
\text { yapmalı mı? }\end{array}$ & $\begin{array}{l}7 \text { kişi evet derken, } 1 \text { kişi (Ö2) gerek yok cevabını } \\
\text { vermiştir. }\end{array}$ \\
\hline 2.Ön görüşmede neler konuşulmalı? & $\begin{array}{l}7 \text { kişi denetlemenin içeriği ve genel durum, } 1 \text { kişi } \\
\text { gerek yok (Ö2) demiștir. }\end{array}$ \\
\hline 3.Ön görüşmeye kimler katılmalı? & $\begin{array}{l}5 \text { kişi başbaşa, Ö6 ve Ö8 idareciler, ben ve denetmen } \\
\text { demiş, Ö2 kişi ise cevap vermemiştir. }\end{array}$ \\
\hline 4.Ön görüşme nasıl bir ortamda olmalıdır? & $\begin{array}{l}5 \text { kişi rahat bir ortamda, } 2 \text { kişi }(0 ̈ 3,0 ̈ 4) \text { ayaküstü } \\
\text { demiș, Ö2 yanıtsız bırakmıștır. }\end{array}$ \\
\hline $\begin{array}{l}\text { 5.Ön görüşmede denetmenin tutum ve tavrı nasıl } \\
\text { olmalıdır? }\end{array}$ & $\begin{array}{l}\text { Ö2, Ö3 yanıtsız bırakmıs, } 6 \text { kişi de yapıcı, samimi, } \\
\text { arkadaşça, açık aramadan, açıllayıcı cevaplarını } \\
\text { vermiștir. }\end{array}$ \\
\hline 6.Sizinle ilgili yorum yapmalı mı? & $\begin{array}{l}\text { Ö6, Ö8 gerek yok, Ö2,Ö3 yanıt vermemiş, } 4 \text { kişi } \\
\text { uygun bir dille yapmalı demiștir. }\end{array}$ \\
\hline 7.Denetleme zamanı önceden bildirilmeli mi? & $\begin{array}{l}\text { Ö2 ve Ö6 bildirilmemeli derken, } 6 \text { kişi bildirilmeli } \\
\text { demistir. }\end{array}$ \\
\hline 8.Denetleme kriterlerini sizinle paylaşmalı mı? & $\begin{array}{l}\text { Ö2,Ö3,Ö4 ve Ö8 paylaşmamalı, 4kişi paylaşmalı } \\
\text { demiștir. }\end{array}$ \\
\hline
\end{tabular}


Yukarıdaki tabloda özetle yanıtların hangi yönde olduğu verilmiştir. Öğretmenlerin çoğunluğu denetlemeye gelecek kişinin kendisiyle ön görüşme yapmasını olumlu bulurken, bir öğretmen bunun gerekli olmadığını düşünmektedir. Olumlu gören öğretmenlerden Ö1 ve Ö3 benzer yanıtlar vererek "Evet. Benden neler beklediğini, ne görmek istediğini yanıma almam için..", "Yapmalı, hazırlıklı olmak için. Evrak hazırlı̆̆ı" diye yanıt vermiştir. Ö4 "Evet. Kendi evimiz gibi düşünürsek, komşu gelmeden önce ev toplanır. Bunun gibi.. Anlık nahoş durumlarla karşılaşmak yanıltıcı olabilir." diye yanıtlarken, Ö5 ön görüşmenin "öğretmeni tanımall, rahatlatmalı" diyerek, ön görüşmenin rahatlatıcı olması gerektiğine dikkat çekmiştir. Ö8 de "daha özenli oluruz, mesela klyafetin daha özenli olur, daha rahat hissetmemiz için gerekli, sonuçta insanlar bilinmeyenden korkarlar" demiştir. Yanıtlara bakıldığında genel olarak ön görüşmenin rahatlatıcı olması, öğretmene hazırlıklı olma şansı tanıması gibi gerekçelerle gerekli bulunduğu görülmüştür. Dağlı (2014)'nın araştırmasına göre de ilköğretim denetmenleri, "derse girmeden önce dersin öğretmeniyle görüşmelidirler" görüşü hakimdir. Bu durum bu araştırmayla paralel çıkmıştır. Yine Yavuz (1995) yaptığı araștırmada denetmenlerin ön görüşmeye yeterinde önem vermedikleri sonucuna ulaşmıștır. Bu araștırma da klasik yöntemin uygulandığı okullarda yaygın olarak görülmektedir.

Öğretmenlere ön görüşmede neler konuşulmalı diye sorulduğunda da Ö5 "genel bilgilendirme", Ö4 "konunun neresinde olduğunu, nasıl gittiklerini, yazılılardaki başarı durumlarını", Ö1 "benden neler beklediği", Ö6 "okulla ilgili genel bilgiler, işleyişi”, Ö7 "denetlemenin içeriği", Ö8 "Hocam dersinize gireceğim demesi bile yeterli" șeklinde yanıtlamışlardır.

Ön görüşmeye 5 öğretmen denetmen ve kendisinin dişında kimsenin katılmasına gerek olmadığını belirtirken, Ö6 ve Ö8 görüşmeye idarecilerin veya başka birilerinin de katılabileceğini belirtmiş, 1 öğretmen ise ön görüşmeyi gereksiz bulduğu için bu soruya yanıt vermemiştir.

Ön görüşmenin nasıl bir ortamda yapılması gerektiğini yordayan soruya ise 5 öğretmen rahat ve uygun bir ortamı tercih ettiklerini belirten cevaplar vermişlerdir. Ö3 ve Ö4 ise ayaküstü görüşme de olabileceğini ifade etmiştir.

Ön görüşmede denetleyecek kişinin tutumu ve tavrının önemini yansıtan görüşler bildirilmiştir. Ö1 "Açıklayıcı ve net konuşmalı", Ö4 "Arkadaş havasında, bağırıp çağırma yok, konuşurken samimi olmalı", Ö5, Ö7, Ö8 “Yapıcl, samimi olmalı”, Ö6 "Açık arar gibi değil, karşıdaki kişiyi incitmeden, gerginlik yaratmadan" şeklinde ifade etmişlerdir. Yani genel anlamda denetmenin tutumu ile ilgili yapıcı, samimi ve uygun üslup kullanmaları gerektiğine vurgu yapmışlardır.

Ön görüşme yapan kişi sizinle yorum yapmalı mı sorusuna cevap veren 4 katılımcı, öngörülerini uygun bir dille paylaşması gerektiğini belirtmişlerdir. Burada da yine üslup ve iletişim tarzına vurgu öne çıkmıştır. Ö8 ise "benim dersime ilk kez giriyorsa derse girmeden yorum yapmasın" demiştir.

Denetleme zamanının önceden bildirilmesi konusunda da öğretmenler farklı görüşler bildirmişlerdir. Ö1 "evet, bildirmelidir, performansı tam olarak değerlendirebileceği bir ders olur" diye yorum yapmış, Ö2 ise "bildirmemeli, aniden gelmeli, ögretmen her an hazırlıklı olmalı", Ö6 "hayır, o zaman hazırlıklı olunur" yorumlarını yapmışlardır. Denetlemenin önceden haber verilmesinin objektif değerlendirme olmayacağını, öğretmenin zaten her zaman eğitim öğretimi yapması gerektiği gibi gerçekleştirmesinin kaçınılmaz olduğunu ifade etmişlerdir.

Kriterlerin paylaşılması ile ilgili maddede de yine benzer görüşler alınmıştır. Ö5 "evet paylaşmalı ki her zaman yapıp, derste o an dikkatimden kaçan bir şey yanıltıcı olmasın" derken, Ö2 "bence bunu denetlemeden sonra yapmalı", Ö4 "hayır, o zaman ögrretmen göz boyayabilir", Ö8 ise "ilk kez denetleniyorsam söylemesin, o beni denetlesin, ben onun dediklerine göre şekil almayayım, ben de kendimi göreyim" şeklinde görüş bildirmişlerdir. Yorumlara bakıldığında, bu konuda bazı öğretmenlerde klasik görüşün hakim olduğu, öğretmenlerin kriterleri öğrenirse olması gerektiğinden farklı davranabileceğini, bu sebeple öncesinde kriterlerin bildirilmemesi gerektiğini söylerken, bazı öğretmenler de tam tersi, her zaman gösterdiği performansın bir ders esnasında uygulanmaması sonucunda yanlış değerlenmeye tabi tutulacaklarından kriterleri bilmeleri gerektiğini söylemişlerdir.

Yapılan analizler neticesinde Mesleki ve Teknik Anadolu Lisesi'ndeki öğretmenlerin tamamı ön görüşmeye olumlu bakmamıș ve hatta bazıları klasik yaklaşımı benimsemişlerdir. 
Bunun sebebi kendilerine ve ders işleyişleri ile ilgili özgüvenleri ve bu zamana kadar hep klasik tarzda denetlenmeye tabi tutulmuş olmaları olabilir.

\section{Gözlem}

Gözlem aşamasında öğretmenlerin performansları sırasında denetmen tarafından veri toplanması ve ders içi değerlendirmesi ile ilgili görüşleri alınmıştır. Alınan cevaplara göre aşağıdaki tablo oluşturulmuştur.

Tablo 4. 'Gözlem' temasına ilişsin sorular ve katılımcı görüşleri

\begin{tabular}{|c|c|}
\hline Sorular & Katılımcı Görüşleri \\
\hline $\begin{array}{l}\text { 1.Denetleme yapacak kişi sizinle ilgili bilgi } \\
\text { toplarken nasıl davranmalı? }\end{array}$ & $\begin{array}{l}\text { Gözlem yapmalı diyen } 4 \text { kişi (Ö1, Ö3,Ö4,Ö5), } \\
\text { idareye sorabilir diyen } 3 \text { kiși (Ö1, Ö6, Ö8), } \\
\text { öğrenciye sorabilir diyen } 1 \text { kişi (Ö6) vardır. }\end{array}$ \\
\hline $\begin{array}{l}\begin{array}{l}\text { 2.Denetleme yapacak } \\
\text { gözlemlemeli? }\end{array}\end{array}$ & $\begin{array}{l}\text { Bütün katılımcılar dersin işleyişi ile ilgili görüşler } \\
\text { bildirmişlerdir. }\end{array}$ \\
\hline $\begin{array}{l}\text { 3.Ders içi denetim sırasında denetmen derse } \\
\text { katılmalı mı? }\end{array}$ & $\begin{array}{l}\text { Ö4, Ö7 ve Ö8 katılmalı derken, diğer katılımcılar } \\
\text { müdahale etmemeli demiștir. }\end{array}$ \\
\hline 4.Sinıftaki tutumu nasıl olmalı? & $\begin{array}{l}\text { Ö8 "kendini belli edebilir" derken, diğer bütün } \\
\text { katılımcılar gözlem yapması gerektiğini, sınıfta } \\
\text { kendini belli etmemesi gerektiğini söylemișlerdir. }\end{array}$ \\
\hline
\end{tabular}

Yukarıdaki tabloya göre sınıf içi gözlem sırasındaki etkinliklerle ilgili olarak genellikle benzer görüşler bildirilmiştir. Denetleme sırasında denetmenin bilgi toplarken, psikolojik baskıyı hissettirmeden gözlem yapmasının uygun olduğu ile ilgili görüşler hakimken, Ö1, Ö3, Ö6 ve Ö8 idareden de bilgi alınabileceğini ifade etmiştir. Ayrıca Ö6 ve Ö8 konuya göre öğrenciden de bilgi alınabileceğini ifade etmiştir.

Denetleme yapacak kişinin sınıfta neleri gözlemlemesi gerektiği sorusuna da genelde ortak yanıtlar verilmiştir. Bunlar "öğrenci ile iletişim, sınıf hakimiyeti, kullanılan yöntem ve teknikler, duruş, ders işleyişi, zaman yönetimi, kılık klyafeti, branşyeterliliği, öğrenci odaklı eğitimin yapılıp yapılmadı, materyal kullanımı" șeklinde görüşler bildirilmiştir. Yani denetmenin sınıf içerisinde ders ve sınıf içi performansın dışında herhangi bir șeyle ilgilenmesi beklenmemektedir.

Ders içi denetim sırasında denetmenin derse katılıp katılmaması ile ilgili görüşlere bakıldığında da Ö7 "evet" ve Ö4, Ö8 "derse katılmalı, öğrencilere konuyla alakalı soru sormalı, ögretmen de bakıp gidiyorlar diye düşünmesin, bir denetleme tedirginliği oluşmalı" șeklinde görüș bildirmiştir. Yani klasik yaklaşımların oluşturduğu denetim gerginliğini ve derse müdahaleyi olumlu bulmaktadır. Diğer katılımcıların ise yorumları 0̈4, Ö7 ve Ö8'in yorumuna ters düşmektedir. Ö2 bu duruma "branş hakkında bilgisi yoksa asla, gözlemlemeli, katılmamalı" şeklinde yorum getirerek özellikle branş hakkında hakimiyet gerekliliğine de dikkat çekmiştir. Kayıkçı ve diğerlerinin (2014) yaptığı araştırmada da buna benzer ifadeler dikkat çekmektedir.

Denetmenlerin sınıftaki tutumları ile ilgili de Ö7 "gözlemci, yeri geldiğinde katılımcı", Ö8 "resmi olmall, öğrenciler de fark edebilir" görüşünü bildirmişlerdir. Bunun dışında diğer katılımcılara ait yorumlar şu şekildedir.

Ö1 "arka sirada gözlem yapmall, soyutlanmalı".

Ö2 "sadece gözlem yapmalı, yargılayıcı hiçbir ifade kullanmamalı, beden dili yargılayıcı olmamal, yoksa objektif olmaz".

Ö3 "yok gibi davranmall, soyutlanmall, en arkada olmalı, gözlem yapmalı".

Ö4 "Öğretmene sınıfının lideri olduğunu hissettirmeli, öğretmenin ders konusunda denetmenden de ön planda olduğunu bilmeli".

Ö5 "otoriter ve sorgulayıcı değil, gözlemci olmalı, öğretmenin otoritesini sarsmamalı" şeklinde görüşler bildirmişlerdir. Görüşlere bakıldığında genel olarak denetmenin sınıfta sorgulayıcı, gerginlik yaratıcı, açık arayıcı bir tarzda olmamalı gerektiği ifade edilmiştir. Bu durum öğretmenlerin denetimden rahatsız olmak istemediklerini, denetimden sinıf içerisindeki otoritelerini sarsmaması gerektiğini düşündüklerini göstermektedir. Yavuz’a (1995) göre klasik denetim yaklaşımıyla denetim yapılan kurumlarda öğretmenler gözlem aşaması ile ilgili olumsuz görüş bildirmişlerdir. Bu durum çağdaş denetim yaklaşımlarındaki yapıcı, rehber, derse müdahale etmeden gözlem yapan denetmen anlayışından uzak bir denetimin ortaya koyduğu izleri 
yansıtmaktadır. Kayıkçı ve diğerlerinin (2014) araştırmasında da okul müdürleri, objektif, yıkıcı olmayan, incitmeden yapılan denetim ve gözlemlerin öğretmenin performansını artırdığı șeklinde görüş belirtmişlerdir.

\section{3. Çözümleme ve Planlama}

Bu aşama gözlem ile son görüşme arasındaki analiz ve planlama sürecidir. Gözlemi yapan denetmen topladığı verileri burada betimler, belli başlıklar altında gruplandırır ve öğretmenle yapacağı son görüşme ile ilgili bazı kararlar alır. Bu aşamaya ait etkinliklerle ilgili sorular ve yapılan görüşler aşağıdaki tabloda özetlenmiștir.

Tablo 5. 'Çözümleme ve Planlama' temasına ilișkin sorular ve katılımcı görüșleri

\begin{tabular}{|c|c|}
\hline Sorular & Katılımcı Görüșleri \\
\hline $\begin{array}{l}\text { 1.Denetleyen kişi } \text { gözlemden sonra } \\
\text { sizinle ilgili bilgileri nasıl yorumlamalı? }\end{array}$ & $\begin{array}{l}\text { Ö3 ve Ö4 o dersle sınırlı kalmaması gerektiğini, diğerleri de } \\
\text { objektif ve mesleki açıdan yanıtlarını vermișlerdir. }\end{array}$ \\
\hline $\begin{array}{l}\text { 2.Denetleyen kişi sizinle denetimden } \\
\text { sonra görüşme yapmalı mı? }\end{array}$ & $\begin{array}{l}\text { Ö3 "gerek yok" ve Ö4 “öğretmene sormalı, isterse görüşmeli” } \\
\text { derken, diğerleri evet yanıtını vermişlerdir. }\end{array}$ \\
\hline 3.Sizce görüşmeyi nasıl planlamalı? & $\begin{array}{l}\text { Ö3 yanıtsız bırakmış, diğer katılımcılar olumludan } \\
\text { olumsuza, neler söyleyeceğini planlamalı demiștir. }\end{array}$ \\
\hline 4.Görüşme nerede ve nasıl olmalı? & $\begin{array}{l}\text { Ö3 yanıtsız bırakırken, diğer katılımcılar baş başa, sakin bir } \\
\text { ortamı tercih etmişlerdir. }\end{array}$ \\
\hline
\end{tabular}

Yukarıdaki görüşlere bakıldığında bir öğretmenin son görüşmeyi gereksiz bulduğu, diğerlerinin ise yapıcı bir görüşmeyle eksikliklerini görüp onları düzeltmeye hazır oldukları ortaya çıkmıştır. Denetleyen kişinin gözlemden sonra bilgileri yorumlarken tek bir dersle kanıya varmaması gerektiği, değerlendirmenin kişisel özellikleri dışarıda bırakarak mesleki açıdan ele alınması gerektiği görüşleri ön plana çıkmıştır. Dağlı'nın 2014'te yaptığı araştırmada da ders içi denetimle ilgili farklı bir noktaya temas edilerek, ilköğretim denetmenleri, "ders denetimi için ayırdıkları süreyi" biraz daha fazla tutmalıdırlar. Gerekirse bu konuda yasal bir düzenlemeye gidilmelidir denilmiştir. Bu durum tek bir derste yapılacak değerlendirmenin yanıltıcılığından duyulan endişedir. Araştırmamızda çıkan ortak görüş de bu ifade ile örtüşmektedir.

Denetleyen kişi sizinle denetimden sonra görüşme yapmalı mı sorusuna Ö3 "gerek yok" cevabını verirken, Ö4 "öğretmene sormalı, isterse görüşmeli" demiştir. Diğer katılımcılar görüşme yapmanın gerekli olduğuna katılmışlar, Ö6 bu durumu "Tabii ki, geribildirim isterim" şeklinde özetlemiştir.

Sizce görüşmeyi nasıl planlamalı sorusuna, Ö3 herhangi bir görüş bildirmezken, Ö2 "bir plan dahilinde gözlem yapacağı için, sonradan bunları öğretmene açıklamalı", Ö4 "yine kriterler üzerinden, kişiselleștirmeden yapmalı", Ö5 "neleri söyleyeceğini, hangi dili kullanacağını planlamalı", Ö6 "konuşacaklarını planlamalı, not almalı", Ö7 "olumludan, olumsuza", Ö8 "plan yapmalı, eksikleri kaçırmamak için" şeklinde yorumlar yapılmıştır. Yorumlara bakıldığında, yapıcı, belli bir düzen dahilinde ve üslup planlaması temalı olması gerektiği görüşü ortaya çıkmıștır.

Görüşmenin nerde olacağı ile ilgili görüşlere bakıldığında ise, 7 katılımcı "başbaşa" yanıtını vermiștir. Bunlardan Ö1 "öğretmeni strese sokmayan, mahkeme gibi değil" ve Ö2 "eğer ciddi sorunlar varsa birebir iletişim, sakin bir ortamda, öğretmenin eksiğini tamamlayacak şekilde, olumlu eleştirilerle, geliştirici olmalı" șeklinde ilavelerde bulunmuşlardır. Ö3 son görüşmeyi gereksiz bulduğu için bu soruyu yanıtsız bırakmıştır.

Yorumlara bakıldığında Mesleki ve Teknik Anadolu Lisesi'nde öğretmenler genel olarak görüşmeden önce planlama yapılması ile ilgili olumlu görüş bildirmişlerdir. Bunu ifade ederken de görüșmenin yapıcı bir dille, gerginlik olușturmadan, uygun bir üslupla ve baș bașa olmasının planlanması gerektiğine dikkat çekmişlerdir. Özan ve Şener'in (2015) araştırmasına göre de öğretmenler denetimin açık arama davranışı olmadan, baskı ve korkuyu ortadan kaldırılarak yapılması gerektiğini ifade etmişlerdir. Yine Kayıkçı, Vantürk ve Yılmaz'ın (2014) araştırmasında da benzer sonuçlar görülürken, aynı zamanda kliniksel yaklaşımda denetmen ve öğretmen arasındaki ilişkinin güçlenebileceği, öğretmenin denetmenden çekinmeyeceği, sorunların tespitinin birlikte ve planlı bir şekilde yapılabileceği görüşleri bildirilmiştir.

\section{Son Görüşme}


$\mathrm{Bu}$ aşama son görüşme sürecidir. Gözlemi yapan denetmen çözümleme ve planlama aşamasında görüşmeyle ilgili başlıkları ve görüşmeyi planladıktan sonra uygun ve öğretmenin rahat edeceği bir ortamda görüşmeyi gerçekleștirir. Bu aşamaya ait etkinliklerle ilgili sorular ve yapılan görüşler aşağıdaki tabloda özetlenmiştir.

Tablo 6. 'Son Görüşme' temasına iliş̧kin sorular ve katılımcı görüşleri

\begin{tabular}{|c|c|}
\hline Sorular & Katılımcı Görüşleri \\
\hline $\begin{array}{l}\text { 1.Denetmen, denetleme sonrası sizinle } \\
\text { hangi gözlemlerini paylașmalı? }\end{array}$ & $\begin{array}{l}\text { Kriterlerde yer alan özelliklere göre olumlu ve } \\
\text { olumsuz yönleri paylașmalı. }\end{array}$ \\
\hline $\begin{array}{l}\text { 2.Sizinle son görüşmeyi yaparken yanınızda } \\
\text { kimler olmalı? }\end{array}$ & $\begin{array}{l}\text { Ö6 idarecinin de olabileceğini eklemiş, diğer } \\
\text { katılımclar kimsenin olmaması gerektiğini } \\
\text { söylemiștir. }\end{array}$ \\
\hline $\begin{array}{l}\text { 3.Paylaşırken nasıl bir yaklaşımda } \\
\text { bulunmalı? }\end{array}$ & $\begin{array}{l}\text { Ö4 amir olduğunu hissettirmeli demiș, diğer } \\
\text { katıllımclar yapıcı, eksik tamamlayıcı demișlerdir. }\end{array}$ \\
\hline 4.Size eksik yönlerinizi belirtmeli mi? & Bütün katılımcılar olumlu görüș bildirmișlerdir. \\
\hline $\begin{array}{l}\text { 5.Daha sonraki ders işleyişinizle ilgili } \\
\text { önerilerde bulunmalı mı? }\end{array}$ & Bütün katılımcılar olumlu görüş bildirmişlerdir. \\
\hline $\begin{array}{l}\text { 6.Yöntem ve tekniklerinizi geliştirirken size } \\
\text { fikir vermeli mi? }\end{array}$ & \\
\hline
\end{tabular}

Yukarıdaki yorumlara bakıldığında genel olarak yapıcı ve uygun bir üslupla olmak koşuluyla eksiklerinin kendilerine söyleneceği ve olumlu yönlerinin de belirtileceği bir son görüșmeye olumlu bakmaktadırlar. Denetmen sizinle hangi gözlemlerini paylașmalı sorusuna, genelde Ö2 "kriterlerini paylaşacak, öğretmen sonra bu neden böyle oldu demesin" șeklinde özetlemiștir.

Öğretmenlerden yalnızca biri (Ö6) son görüşme sırasında idarecinin de olabileceğini ifade ederken diğer katılımcılar baş başa yapılması gerektiğini söylemişlerdir. Görüşmede nasıl bir dil kullanılmalıdır sorusuyla ilgili ise, Ö4 "amir olduğunu hissettirmeli" şeklinde farklı bir bakış açısı ifade etmiştir. Bu yorum denetmenin üstün olduğu klasik denetim yaklaşımlarıyla örtüşmektedir. Diğer katılımcılar genel olarak "açıklayıcı olmalı" (Ö3), "otoriter değil, rehber, olumlu, ben dili, yargılamadan, eksik tamamlayıcl, eleștirici" (Ö2, Ö5, Ö7, Ö8) șeklinde görüş bildirmişlerdir. Ö1 bu yorumlara "benden daha iyi bilen biri olmalı" şeklinde yorum yapmıştır. Bu durumu Yavuz da (1995) yaptığı araştırmasında denetimden beklenen verimin alınmasının denetmenlerin eğitimöğretim konularında öğretmenden daha fazla bilgiye sahip olmalarıyla doğru orantılı olduğunu söyleyerek ifade etmiştir. Denetmeni öğretmenlerin öğretmeni olarak tanımlamaktadır. Ama ne yazık ki aynı araştırmada denetmenlerin öğretmenler tarafından başvurulacak kişi olmadıkları belirtilmiştir. Yine aynı şekilde Kayıkçı ve diğerlerinin (2014) araştırmasında da denetleyecek kişinin alandan gelmiş olması, rehberlik yapacak düzeyde alan bilgisine sahip olması gerektiği görüşleri belirtilmiştir.

Yine eksik yönlerinizi belirtmeli mi, daha sonraki ders işleyişinizde, yöntem ve tekniklerinizde size fikir vermeli mi sorularına katılımcıların tamamı olumlu görüş bildirmişlerdir. Görüldüğü gibi yorumlar, Mesleki ve Teknik Anadolu Lisesi'ndeki öğretmenler yapıcı, rehber, samimi bir yönlendiriciyi istemektedirler ayrıca son görüşmeyle ilgili olumlu görüş bildirmektedirler. Bunu ifade ederken de görüşmenin yapıcı bir dille, gerginlik oluşturmadan, uygun bir üslupla ve baş başa olması gerektiğine dikkat çekmişlerdir.

\section{Eleștiri}

Bu aşama eleştiri sürecidir. Denetleme ile ilgili dört aşamayı tamamladıktan sonra yapılan denetimle ilgili de geliştirici ve yansıtıcı bir aşama olan eleştiri aşamasına ait etkinliklerle ilgili sorular ve yapılan görüşler aşağıdaki tabloda özetlenmiștir.

Tablo 7. 'Eleștiri' temasına ilişkin sorular ve katılımcı görüșleri 


\begin{tabular}{|ll|}
\hline 1. Sonuçları sizinle tartışmalı mı? & $\begin{array}{l}\text { Ö2, Ö4 ve Ö6 hayır yanıtını verirken, diğer } 5 \\
\text { katılımcı olabilir yanıtını vermișlerdir. }\end{array}$ \\
\hline $\begin{array}{l}\text { 2.Sizinle denetimin etkililiği ve işe yararlı̆̆ı } \\
\text { konusunda tartışmalı mı? }\end{array}$ & $\begin{array}{l}\text { Ö3, Ö5 ve Ö8 evet, diğer } 5 \text { katılımcı benden bilgili } \\
\text { olmalı, bana sormamalı demiștir. }\end{array}$ \\
\hline $\begin{array}{l}\text { 3.Yaptığı denetimle ilgili sizinle olan } \\
\text { görüșmelerini eleștirmeli mi? }\end{array}$ & \begin{tabular}{l} 
Ö6 ve Ö7 gerek yok, diğer katılımcılar evet \\
\hline 4. Eleștiri dili nasıl olmalı?
\end{tabular} \\
\hline
\end{tabular}

Yukarıdaki yorumlara bakıldığında farklı yorumlar görülmektedir. Bu aşamada denetmenin kendi yaptığı uygulamayla ilgili bir eleștiri yapma fikri katılımcılara oldukça yeni ve yabancı gelmiş, cevaplarda çelişkiye düşmüşlerdir. Sonuçları sizinle tartışmalı mı sorusuna Ö2, Ö4 ve Ö6 gerek görmezken, Ö4 bunu "hayır, kendi bildiğini yapmalı", Ö2 ise "kriterler netse tartışılacak bir şey yoktur" şeklinde ifade etmişlerdir. Diğer katılımcılar tartışılabileceğini belirtmişlerdir.

Denetimin etkililiği ve işe yararlılığı konusunda tartışılmalı mı sorusuna, Ö1 "zaten yeterliliği olan biri olduğu için ben eleştiremem, bana not ermesin, rehberlik yapsın", Ö2 "işini doğru yapan bir denetmen bunu zaten yapar", Ö4 "Hayır, o kendi amirleriyle bunu tartışmalı", Ö5 "evet, tartışmalı, işe yarar hale dönüştürülmeli" şeklinde görüşler bildirmişlerdir. Ayrıca yaptığı denetimle ilgili sizinle olan görüşmelerini eleştirmeli mi sorusuna da, Ö1 ve Ö6, Ö7 "gerek yok, otoritesini sarsmasın", Ö2 "böyle bir iletişim şekli olsa mükemmel olurdu, ben de denetmeni denetler durumda olurdum, böyle bir denetmen olduğunu düşünmüyorum", ö8 "genellikle konuşmazlar, ama konuşabilirler" șeklinde görüş bildirirken diğerleri "evet eleștirmeli" șeklinde görüş bildirmişlerdir. Yanıtlardan anlaşıldığı kadarıyla bazı öğretmenler denetmeni denetleme düzeyinin kendi yetkilerinin üzerinde olduğunu, bunun denetmenin otoritesini sarsabileceğini, eğer böyle bir yöntem varsa bunun etkili olabileceğini ifade etmişlerdir. Buradan anlaşıldığı kadarıyla DISSMTAL'deki öğretmenler kendilerine bu şekilde sorular yönelten veya bu yönde bir denetim gerçekleştiren bir denetmenle henüz karşılaşmamışlardır ve bunun olabileceğine inanmamaktadırlar.

Son olarak eleștiri dilinin yapıcı ve olumlu olması gerektiğini ifade ederek öğretmenler denetmenlerin rehber, yönlendirici, uygun üslup ve iletişim teknikleriyle ilişki kuran, yargılayıcı ve sorgulayıcı, açık arayıcı olmayan bir yaklaşımda bulunması gerektiğini ifade etmişlerdir.

Genel olarak katılımcıların kliniksel denetimin temalarına katılma durumlarını gösteren tablo aşağıdaki gibidir.

Tablo 8. Katılımcıların Kliniksel Denetimin temalarına katılma durumları

\begin{tabular}{|c|c|c|c|c|c|}
\hline Katılımcilar & Ön Görüşme & Gözlem & $\begin{array}{l}\text { Çözümleme } \\
\text { ve Planlama }\end{array}$ & Son Görüşme & Eleştiri \\
\hline 0̈1 & + & + & + & + & + \\
\hline 0̈2 & - & + & + & + & + \\
\hline 0̈3 & - & + & - & + & + \\
\hline $0 \ddot{4}$ & + & + & + & + & - \\
\hline 0̈5 & + & + & + & + & + \\
\hline 0̈6 & - & + & + & + & - \\
\hline 0̈7 & + & + & + & + & - \\
\hline 0̈8 & + & + & + & + & + \\
\hline
\end{tabular}

Yukarıdaki tabloda alt temalarla ilgili olumlu görüş bildirenlere (+), olumsuz görüş bildirenlere (-) verilmiştir. Bu tablodan anlaşıldığı kadarıyla öğretmenler genel olarak ön görüşme ve eleştiri boyutlarıyla ilgili farklı görüşler bildirmiş, diğer boyutlarla ilgili olumlu görüş bildirmişlerdir. Bu da kliniksel denetimin 5 aşamasının da Mesleki ve Teknik Anadolu Lisesi'nde uygulanması ile ilgili sıkıntılar yaşanabileceğini göstermektedir. Kayıkçı ve diğerlerinin (2014) yaptığı araştırmaya göre de okul müdürlerinden bazıları kliniksel yaklaşımın kısmen uygulanabileceğini düşünerek, her aşamasının uygulanması mümkün olmasa da bazı aşamalarının uygulanmasının diğer denetimlere oranla daha iyi olacağını ifade etmişlerdir. Yine bazı okul müdürleri ise kalabalık okullarda bu uygulamanın zaman alacağını, bu zamana kadar sürekli açığı aranılan öğretmene bu yaklaşımın uygulanmasının çok zor olduğunu dile 
getirmişlerdir. Görüşlere bakıldığında çıkan sonuçlar, araştırmamızın ifadeleriyle benzerlik taşımaktadırlar.

Ayrıca görüşmeler dişında yapılan gözlemler sonucunda da okula denetlemek amaçlı olarak İl Milli Eğitim Müdürlügü'nden Şube Müdürlerinin geldiği, bunun dışında gelen maarif müfettişlerinin ikili ilişkilerden dolayı, ziyaret sebebiyle okula geldiği, herhangi bir denetim amacıyla gelmedikleri görülmektedir. Ayrıca okul müdürü ders içi denetimlere girmekte, bunu da kliniksel denetim yaklaşımına uygun olarak öğretmenin isteği ve daveti ile gerçekleştirmekte fakat sonraki aşamaların, klinik denetim hakkındaki sürecin bilinmemesi sebebiyle klasik yaklaşımla sonlandırıldığı görülmektedir. Öğretmene fikrinin ve isteğinin sorulması bu yaklaşım açısından olumlu bir adım olarak görülmektedir.

\section{TARTIŞMA ve SONUÇ}

$\mathrm{Bu}$ araştırmada Mesleki ve Teknik Anadolu Lisesi'nde görev yapan idareci ve öğretmenlerin kliniksel denetimin alt temalarıyla ilgili görüşleri alınmış ve görüşmeler analiz edilmiştir. Yapılan analiz sonucunda aşağıdaki sonuçlara ulaşılmıştır:

1. Mesleki ve Teknik Anadolu Lisesi'ndeki öğretmenlerin yorumlarına ve beklentilerine bakıldığında standartlara ve nesnel kurallara dayalı olan bilimsel denetim yaklaşımının izleri görülmektedir.

2. Öğretmenlerden 3 'ü kliniksel denetim yaklaşımının ön görüşme aşamasını gereksiz bulmuşlardır.

3. Gözlem temasında denetmenin soyutlanmıș olmasını ve sürece müdahil olmamasını, ders ve meslekle ilgili gözlemler yapması gerektiğini savunmuşlardır.

4. Çözümleme ve planlama temasını gerekli bulmuş, bu aşamada objektif betimlemeler yapmaları gerektiğini belirtmişlerdir.

5. Son görüşmenin gerekliliğini ifade ederek buradaki görüşmelerde iletişim tekniklerinin kullanılması gerektiğini ve yapıcı olmaları gerektiğini ifade etmişlerdir.

6. Ayrıca öğretmenlerin tamamı kendi eksik yönlerini görmeye ve düzeltmeye sıcak bakmışlardır.

7. Denetmenin uygulamasının eleştirilmesini fikrine yabancı oldukları anlaşılmakta ve 3'ü bunu gereksiz bulmaktadır.

8. Mesleki ve Teknik Anadolu Lisesi'nde kliniksel denetim yaklaşımının bu durumda uygulanmasının etkili olmayacağı düşünülmektedir.

9. Öğretmen ve idarecilere bu yaklaşımın tanıtılması gerekliliği ortaya çıkmıştır.

Yukarıda görüldüğü gibi kurumda kliniksel yönetimin uygulanmasının etkili olmayacağı kanısına varılmıştır. Kurumda kliniksel yaklaşımın her temasıyla ilgili olumlu yanıt bildiren öğretmen sayısı dörttür. Bu durum bütün öğretmenlerin bu yaklaşımla denetlenmesinin uygun olmayacağını göstermektedir. Bunun nedeni öğretmenlerin geçmişteki denetim tecrübelerinin klasik tarzda olması nedeniyle, oluşan izlenim olabilir. Denetime yaklaşımları bu yönde şekillenmiş ve başka bir denetim şekline yabancı kalmış olabilirler. Özan ve Şener (2015) tarafından yapılan çalışma sonucunda da buna değinilmiştir. Araştırmaya göre, denetim sürecine ilişkin olumsuz algıya sahip öğretmenler, bunun gerekçesi olarak denetimin açık aramak ve kontrol amaçlı yapıldığını, bu durumun ise baskı ve korkuya neden olduğunu ileri sürmüşlerdir. Yine Yavuz'un (1995) yaptığı araştırma sonuçlarında da öğretmenlerin denetim konusundaki görüşleri, klasik denetimin izleri görülmektedir. Öğretmenler denetmenleri başvurulacak kişi olarak görmemekte, denetimden uzak kalmak istemekte, denetmenlerin iletişimini yetersiz bulmakta, isteksiz kalmaktadırlar. Aynı şekilde yine Özan ve Şener'in (2015) araştırmasında da öğretmenlerin denetime bakış açıları benzer şekilde görülmüştür. Denetimi kontrol aracı, polis sorgusu, diken üzerinde durmak gibi ifadelerle tanımlamışlardır. Bu sonuçlar öğretmenlerin çağdaş denetim yaklaşımlarına olan ihtiyacını ortaya koymaktadır.

Ayrıca kliniksel denetim yaklaşımı ayrı bir eğitim gerektirmektedir. Uygulanabilmesi için denetleyen ve denetlenenlerin konuya hakim olması, kliniksel yaklaşımı bütün boyutlarıyla tanıması gerekmektedir. Kayıkçı ve diğerlerinin (2014) yaptığı araştırmada da okul müdürlerinden bazıları "tüm eğitimcilerin bu konuda bir eğitimden geçirilmelidirler", "önce 
denetmenler, sonra da okul müdürlerine eğitim verilmeli" fikirlerini savunmuşlardır. Mesleki ve Teknik Anadolu Lisesi'nde bu konuda eğitim alınmamış olması da denetime olan yaklaşımı etkilemiş olmaktadır.

Öğretmenlerin denetmenlerin iletişimi konusunda genellikle rehber olan, yargılayıcı ve açık arayıcı olmayan, yol gösterici ve eksik tamamlayıcı olması, yapıcı iletişim kurması noktalarına dikkat çekmeleri, denetimden çağdaş denetim yaklaşımlarının özelliklerini beklediklerini göstermektedir. Fakat bunun yanı sıra, denetmenin otoritesini kabul eden ve onu sorgulamaya karşı gelen öğretmen görüşleri de mevcuttur. Bu durum kliniksel denetime ters düşmektedir. Yavuz'un (1995) yaptığı araştırmada da öğretmenler denetmenleri, son görüşme, ön görüşme gibi iletişim isteyen basamaklarda isteksiz ve yetersiz bulmaktadırlar.

Denetimden önce öğretmene kriterlerin belirtilmesi nadiren olumsuz görülürken, denetim zamanının haber verilmesi durumuna öğretmenlerin çoğu olumsuz yanıt vermişlerdir. Denetimin haber verilmesinin ve kriterlerin belirtilmesinin öğretmenlerin gerçek performanslarını sergilemelerine engel olacağı düşünülmektedir. Bu nedenle öğretmenler ön görüşmeye de çelişkili yanıtlar vermişlerdir.

Ayrıca denetimin ve denetmenin eleștirilmesi konusu öğretmenlere yabancı gelmiș, bu konuya haklarının olmadığını düșünmüșlerdir. Fakat böyle bir uygulama olursa olumlu bulacaklarını ifade etmişlerdir. Analizlerin sonuçlarına göre öğretmenlere çağdaş denetim yaklaşımlarının tanıtılması sonucunda olumlu yanıtlar alınabileceği görülmektedir. Bu durum böyle bir yaklaşımın uygulamasına geçilmeden önce bir eğitime tabi tutmanın gerekliliğini ortaya koymaktadır.

Araştırmada elde edilen veriler doğrutusunda şu önerilerde bulunulabilir;

1. Mesleki ve Teknik Anadolu Lisesi'nde denetime yönelik algının değiştirilmesi için farklı ve yeni denetim yaklaşımlarının uygulanması gerekmektedir.

2. Öğretmenlere ve yöneticilere denetim yaklaşımları hakkında bilgi verilmesi gerekmektedir.

3. Yapılacak denetimlerle ilgili denetlenecek kişiye ön bilgi verilmelidir.

4. Denetimlerden sonra konu ile ilgili öğretmen ve yöneticilere geribildirim verilmelidir.

5. Öğretmen ve yöneticiler denetimde düzeltme ve rehberliğe sıcak bakmışlardır. $\mathrm{Bu}$ sebeple yapılan denetimin bu yönü ön plana çıkarılmalıdır.

6. Kliniksel denetimin okulda uygulanabilmesi için bir eğitim verilmesi bu eğitimden sonra bu yaklaşımın uygulanmasının verimli olabileceği düşünülmektedir.

7. Bu okulda diğer çağdaş denetim yaklaşımlarıyla ilgili başka yordayıcı çalışmalar da yapilabilir.

8. Bu çalışmaya benzer araştırmalar başka okullarda da yapılarak kuruma uygun olan denetim modelleri yordanabilir.

9. Kurumlarda uygulanacak denetim modelleri bu şekilde bir ön çalışma ile tespit edilerek verimli olabilecek modelin belirlenmesine katkıda bulunabilir.

\section{KAYNAKÇA}

Aydın, İ. (2012). Öğretimde Denetim (3. Baskı). Ankara: Pegem Akademi.

Dağlı, A. (2014). İlköğretim Öğretmenlerinin Algılarına Göre İlköğretim Denetmenlerinin Ders Denetimine İlişkin Davranışları. $\quad$ Eğitim ve vilim. http://egitimvebilim.ted.org.tr/index.php/EB/article/view/5301 adresinden 12 Nisan 2017 tarihinde indirilmiștir.

Erişmen, H. (2008). Ortaöğretimde Klinik Denetim Modeline Yönelik Öğretmen Görüşleri. Yakın Doğu Üniversitesi, Eğitim Bilimleri Enstitüsü, Eğitim Yönetimi, Denetimi, Ekonomisi ve Planlaması Ana Bilim Dall, Yüksek Lisans Tezi: Lefkoșa.

Glickman, C.D., Gordon, S.P. ve Ross-Gordon, J.M. (2014). Denetim ve Öğretimsel Liderlik: Gelişsimsel Bir Yaklaşım. (Editörler: Mualla Bilgin Aksu ve Esmahan Ağaoğlu). Ankara: Anı Yayıncllık. 
Gül, İ. ve Gündüz, Y. (2016). Eğitimde Denetim ve Değerlendirme. (Editörler: Mahmut Sağır ve Süleyman Göksoy). Ankara: Pegem Akademi.

Karakuş, M. (2010). Çağdaş Denetim Yaklaşımları. Fırat Üniversitesi Sosyal Bilimler Dergisi, 20(2), 181-200.

Kayıkçı, K., Vantürk, G. ve Yılmaz, O. (2014). Okul Müdürlerinin Kliniksel Denetime İlişsin Genel Algı ve Değerlendirmeleri. Educational Administration: Theory and Practice, 20(2), 217-249.

Kurt, S. (2009). İlköğretim Kurumlarındaki Yöneticilerin Denetleme Faaliyetlerine İlişkin Yönetici Görüşlerinin Değerlendirilmesi. Trakya Üniversitesi Sosyal Bilimler Enstitüsü, Eğitim Bilimleri Anabilim Dall, Eğitim Yönetimi, Teftiși, Planlaması ve Ekonomisi Bilim Dall, Yüksek Lisans Dönem Projesi: Edirne.

Özan, M., Șener, G. (2015). Sınıf Öğretmenlerinin Denetim Sürecine İlişkin Algı ve Beklentilerinin Metaforlar Aracılı̆̆ı İle Belirlenmesi. Eğitim Bilimleri Dergisi, 41, 19-33.

Özdeğerlendirme MEB Portalı. (2017). http://eokul-meb.tk/blog.php/ozdegerlendirme/

Özmen, F. (2000). Klinik Denetim Öngörüleri Çerçevesinde Denetçi Görüşleri, Fırat Üniversitesi Sosyal Bilimler Dergisi, 10(1), 119-157.

Şişman, M. (2014). Öğretim Liderliği(5.Baskı). Ankara: Pegem Akademi.

Yavuz, Y. (1995). Öğretmenlerin Denetim Etkinliklerini Klinik Denetim İlkeleri Açısından Değerlendirmeleri: İzmir Örneği. Dokuz Eylül Üniversitesi Sosyal Bilimler Enstitüsü Eğitim Bilimleri Anabilim Dalı Eğitim Yönetimi ve Denetimi Programı Yüksek Lisans Tezi, İzmir.

Yıldırım, A. ve Şimşek, H. (2008). Sosyal Bilimlerde Nitel Araştırma Yöntemleri, (6. bs.), Ankara: Seçkin Yayınları.

Yılmaz, G. K. (2015). Durum Çalışması, (Ed.) M. Metin Eğitimde Bilimsel Araştırma Yöntemleri. (s.261-285), Ankara, Pegem A Akademi. 